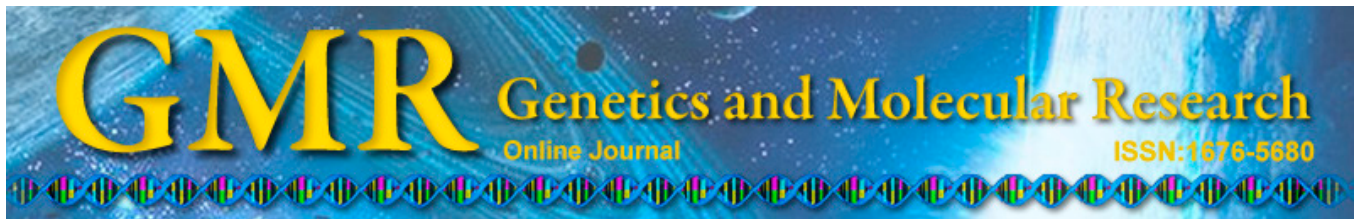

\title{
Confined housing system increased abdominal and subcutaneous fat deposition and gene expressions of carbohydrate response element-binding protein and sterol regulatory element-binding protein 1 in chicken
}

\author{
Q. Li ${ }^{1,2 *}$, X.L. Zhao ${ }^{1 *}$, E.R. Gilbert ${ }^{3}$, Y.P. Liu ${ }^{1}$, Y. Wang ${ }^{1}$, M.H. Qiu ${ }^{1}$ and \\ Q. Zhu $^{1}$ \\ ${ }^{1}$ College of Animal Science and Technology, Sichuan Agriculture University, \\ Ya'an, Sichuan Province, China \\ ${ }^{2}$ Sichuan Animal Science Academy, Chengdu, Sichuan, China \\ ${ }^{3}$ Department of Animal and Poultry Sciences, \\ Virginia Polytechnic Institute and State University, Blacksburg, VA, USA \\ *These authors contributed equally to this study. \\ Corresponding author: Q. Zhu \\ E-mail: zhuqing5959@163.com
}

Genet. Mol. Res. 14 (1): 1220-1228 (2015)

Received June 24, 2013

Accepted January 26, 2015

Published February 6, 2015

DOI http://dx.doi.org/10.4238/2015.February.6.24

\begin{abstract}
Free-range production system is increasingly being used in poultry breeding and feed production in many countries. The objective of the current experiment was to evaluate the effects of different raising systems on fat-related traits and mRNA levels of liver lipogenesis genes in Erlang Mountainous chicken. Each of 10 birds (91 day old) from caged, indoor-floor housed, and free-range housing systems was slaughtered, and fat-related traits, live body weight (BW), subcutaneous fat thickness (SFT), abdominal fat weight (AFW), abdominal fat percentage (AFP), and intramuscular fat content were determined. The mRNA levels of liver
\end{abstract}


$\mathrm{X}$ receptor $\alpha$, carbohydrate response element-binding protein (ChREBP), sterol regulatory element-binding protein-1 (SREBPI), and fatty acid synthase were detected. The caged chicken exhibited significantly higher $\mathrm{BW}, \mathrm{SFT}$, and AFW than those of free-ranged chicken $(\mathrm{P}<0.05)$. All the 4 genes had a similar expression pattern, and they showed the highest level in caged chicken, while the lowest level was found in free-ranged chicken. Association analysis indicated that there were significant $(\mathrm{P}<$ $0.05)$ or highly significant $(\mathrm{P}<0.01)$ positive correlations between the mRNA levels of ChREBP, SREBPI, and fat traits of SFT, AFW, and AFP. Thus, we deduced that increased fat deposition in caged chicken was probably induced by increased gene expression of ChREBP and SREBPI in the liver.

Key words: Chicken; Fat-related traits; Gene expression; Housing system

\section{INTRODUCTION}

In China, raising chickens in a free-range system is a traditional practice that supports the geographical and cultural environment. Consumers increasingly prefer chicken products from a free-range system because of animal welfare and food safety concerns, as well as due to the perceived nutrition and flavor of the meat. Studies comparing different rearing systems have shown that conventional caging systems place social and biological pressure on the chicken (Jones and Mills, 1999), resulting in physiological and behavioral disorders (Marin et al., 2001) and reduced performance (Mendl, 1999). An outdoor, confinement-free system might prevent stress, enhance comfort and bird welfare, reduce abdominal fat (Wang et al., 2009a), and enhance meat flavor (Fanatico et al., 2006). Thus, a free-range rearing system could be advantageous for animal health and welfare and meat quality.

Fat-related traits are important factors that can be used to evaluate meat quality and flavor (Wood et al., 2008). In birds, liver is the major site of de novo lipogenesis, and most of the lipids that accumulate in the white adipose tissue originate from triacylglycerols that are synthesized by plasma lipoproteins in the liver, or are provided from dietary fats (Griffin and Hermier, 1988). Hence, investigating the key regulators of hepatic lipid synthesis is important to explore the mechanisms involved in the effects of different rearing systems on the changes in carcass fat deposition.

Sterol regulatory element-binding proteins (SREBPs) are transcription factors from the basic-helix-loop-helix leucine zipper (bHLH/LZip) transcription factor family. Different studies have shown that SREBPs can directly stimulate the transcription of acetyl CoA carboxylase $(A C C)$, fatty acid synthase $(F A S)$, and stearoyl CoA desaturase $(S C D 1)$ genes (Magana et al., 1997; Tabor et al., 1999). Two SREBP genes (SREBP1 and SREBP2) have been identified in mammals that produce 3 protein isoforms (SREBP-1a, SREBP-1c, and SREBP-2). Among them, SREBP-1c is the major isoform involved in the regulation of lipogenic gene expression (Dentin et al., 2005). Carbohydrate response element-binding protein (ChREBP) is another bHLH/LZip transcription factor known to work cooperatively with SREBP-1c in the regulation of lipogenic gene expression. It can regulate the gene expression of lipogenic (ACC and FAS) and glycolytic factors in response to glucose (Uyeda and Repa, 2006). FAS catalyzes the 
last step in the fatty acid biosynthetic pathway. It is a key determinant for the maximal capacity of a tissue to synthesize fatty acids via the de novo pathway (Clarke, 1993). Liver X receptor $\alpha$ $(\mathrm{LXR} \alpha)$ is a member of a nuclear hormone receptor super-family, proteins that can coordinate gene expression in response to hormonal and environmental signals (Proszkowiec-Weglarz et al., 2008; Demeure et al., 2009). Recently, many studies have shown that LXR $\alpha$ is a master transcription factor governing hepatic lipogenesis in mammals. LXR $\alpha$ regulates the expression of ACC (Talukdar and Hillgartner, 2006), SCD1 (Chu et al., 2006), and FAS (Joseph et al., 2002), all of which are central enzymes in the pathway of de novo lipogenesis. It can also influence the expression of 2 transcription factors involved in lipogenesis: ChREBP through the glucose pathway and SREBP-1c through the insulin pathway (Repa et al., 2000; Cha and Repa, 2007), Therefore, $L X R \alpha$ together with ChREBP, SREBP1, and FAS belong to a network involved in the control of hepatic fatty acid synthesis (Ducheix et al., 2011).

A few studies have focused on the cloning and tissue-specific expression of these lipogenic factors in chickens. The ChREBP and SREBPI genes showed the highest expression in the liver, and $L X R \alpha$ was able to regulate the mRNA expression of FAS (Proszkowiec-Weglarz et al., 2008; Demeure et al., 2009). This suggests that the functions of these genes are conserved between chickens and mammals. The objective of the present study is to evaluate the effect of different rearing systems on fat-related traits and mRNA abundance of $L X R \alpha, C h R E B P, S R E B P 1$, and $F A S$, as well as to determine the association between them. We expected to explain the changes in fat-related traits caused by different rearing systems from the level of gene transcription.

\section{MATERIAL AND METHODS}

\section{Experimental materials and management}

The population used in the current study, SD02 x SD03, was a cross between pure lines SD02 and SD03 of Erlang Mountainous chicken. Both pure lines are characterized by spotty feathers with a yellow background and black skin as described by Zhao et al. (2012). During the rearing of 5 generations at our facility, phenotypic selection emphasized body weight (BW) in Line SD02 and egg production in Line SD03. The Erlang Mountainous chicken is famous for its delicious meat and moderate growth rate. Fertilized eggs were obtained from matings (by artificial insemination) of Lines SD02 and SD03 and hatched at the farm of Sichuan Agricultural University. At hatch, a group of chicks were vaccinated and transported to the breeding base (located at $30^{\circ} 02^{\prime} \mathrm{N}$ and $102^{\circ} 36^{\prime} \mathrm{E}$ at $1079 \mathrm{~m}$ in altitude). From days 1 to 42 , chicks (without determined sex) were reared in concrete floor pens with wood shavings as litter (heat was provided using a chimney flue). At day 43, 800 chickens (half of which were male and the other half, female), with similar BW (314.6 $\pm 24.1 \mathrm{~g})$, were selected and randomly assigned to 3 treatment groups (caged: 200 chickens; indoor-floor housed: 200 chickens; and free-ranged: 400 chickens). Caged chickens were raised in 20 conventional cages that contained plastic hollowed pads $\left(1.9 \times 1.0 \times 0.7 \mathrm{~m} ; 5.3 \mathrm{bird} / \mathrm{m}^{2}\right)$. Chickens of the indoor-floor housed group were raised in pens covered with wood shavings $\left(3 \times 5 \times 2.7 \mathrm{~m}, 3.3 \mathrm{bird} / \mathrm{m}^{2}\right)$. They were equipped with equal sized playgrounds outside the house. Chickens in the outdoor free-range treatment were raised in grass paddocks under pine trees $\left(1,334 \mathrm{~m}^{2}, 0.3 \mathrm{bird} / \mathrm{m}^{2}\right)$. Chickens were allowed free range during daylight hours while feeding and confined to the shelter at night. During the indoor treatment, birds were provided a constant photoperiod of 24 h. During the outdoor treatment, they were provided photoperiod by natural daylight. 
All birds were fed the same diet. Feed and water were freely available, and diets were formulated to satisfy the nutrition demands of Erlang mountainous chickens, as described by the Feeding Standard of Chicken in China (NY/T 33, 2004).

\section{Trait measurement and sample collection}

At day 91, 10 chickens (ratio of male to female was 1:1) from each treatment were randomly selected and weighed after 12-h feed withdrawal.

After birds were slaughtered, the skin thickness in front of caudal sebaceous glands, along the dorsal midline incision (SFT) and abdominal fat pad and fat around gizzard (AFW) weights were measured, and the ratio of AFW to BW (AFP) was calculated. Samples were collected from the left pectoralis major muscle and stored at $-20^{\circ} \mathrm{C}$. The Soxhlet extraction method was then used for the determination of intramuscular fat content (IMF) (Zerehdaran et al., 2004).

Samples of liver were collected, snap-frozen in liquid nitrogen, and then stored at $-80^{\circ} \mathrm{C}$ for total RNA isolation.

\section{RNA isolation and reverse transcription}

Total RNA was extracted from the liver samples by using Trizol reagent (Invitrogen, Carlsbad, CA, USA) according to manufacturer instructions. The quantity and purity of total RNA was evaluated using spectrophotometry at 260, 280, and $230 \mathrm{~nm}$. The RNA integrity was evaluated by $1.5 \%$ agarose gel electrophoresis. Reverse transcription of total RNA was performed using Oligo-dT 12-18 primers according to manufacturer instructions (TaKaRa, Biotechnology Co. Ltd., Dalian, China). The reactions were performed in $25 \mu \mathrm{L}$ volumes that consisted of $1.0 \mu \mathrm{L} 1 \mu \mathrm{g} / \mu \mathrm{L}$ total RNA, 50 U Superscript III reverse transcriptase (Invitrogen Biotechnology Co. Ltd., Shanghai, China), 40 U RNAse inhibitor (Invitrogen Biotechnology Co. Ltd., Shanghai, China), $0.5 \mathrm{mM}$ dNTPs, and $100 \mathrm{ng}$ random hexamer primers (Invitrogen Biotechnology Co. Ltd., Shanghai, China).

\section{Primers and standard curve preparation} Oligo 6.0.

The primer information for all genes is listed in Table 1. Primers were designed using

\begin{tabular}{|c|c|c|c|c|c|}
\hline Genes $^{1}$ & Orientation & Primer sequence $\left(5^{\prime}-3^{\prime}\right)$ & Accession No. & Product size (bp) & Annealing temperature $\left({ }^{\circ} \mathrm{C}\right)$ \\
\hline$L X R \alpha$ & $\begin{array}{l}\text { Sense } \\
\text { Antisense }\end{array}$ & $\begin{array}{l}\text { TCCCTGGTGGAGAGACTACAGC } \\
\text { TACTTAGCGTCCGAAGACTGACC }\end{array}$ & NM_204542.2 & 152 & 58.2 \\
\hline ChREBP & $\begin{array}{l}\text { Sense } \\
\text { Antisense }\end{array}$ & $\begin{array}{l}\text { GCCTGGAGACCAACAGAGAAAT } \\
\text { AGATGTAAGAGAGGAATGTGTC }\end{array}$ & NM_001110841.1 & 151 & 62.4 \\
\hline SREBPI & $\begin{array}{l}\text { Sense } \\
\text { Antisense }\end{array}$ & $\begin{array}{l}\text { GATGCGTTGGAGTACCTTCAG } \\
\text { GTCACCCTTCAGCCAGTGAAT }\end{array}$ & NM_204126.1 & 168 & 59 \\
\hline$F A S$ & $\begin{array}{l}\text { Sense } \\
\text { Antisense }\end{array}$ & $\begin{array}{l}\text { AAGCAATTCGTCACGGACAG } \\
\text { GGCACCATCAGGACTAAGCA }\end{array}$ & $\mathrm{J} 03860$ & 116 & 61.8 \\
\hline$\beta$-actin & $\begin{array}{l}\text { Sense } \\
\text { Antisense }\end{array}$ & $\begin{array}{l}\text { GAGAAATTGTGCGTGACATCA } \\
\text { CCTGAACCTCTCATTGCCA }\end{array}$ & NM_205518 & 180 & 60 \\
\hline
\end{tabular}

${ }^{1} L X R \alpha=$ liver $\mathrm{X}$ receptor $\alpha$; ChREBP = carbohydrate response element-binding protein; $S R E B P 1=$ sterol regulatory element-binding protein-1; $F A S=$ fatty acid synthase. 
Each gene-specific primer pair was amplified, and the PCR products were resolved on $2 \%$ agarose gels and then recovered from the excised gel fragments by using a Gel Extraction Mini Kit (Omega, Biotechnology Co., USA). After the specificity was varied by direct DNA sequencing, standard curves were constructed from 10-fold serial dilutions of the purified PCR products to determine the suitable conditions and assess amplification efficiency.

\section{Real-time polymerase chain reaction (PCR)}

The mRNA abundance of each gene was measured using real-time PCR using a BioRad CFx96 ${ }^{\mathrm{TM}}$ (Bio-Rad, USA) system and SYBR Green chemistry. PCR was performed in 15 $\mu \mathrm{L}$ volumes containing $1 \mu \mathrm{L}$ cDNA, $0.6 \mu \mathrm{L} 10 \mu \mathrm{M}$ reverse and forward primers for each gene, $5.3 \mu \mathrm{L} \mathrm{ddH_{2 }} \mathrm{O}$, and $7.5 \mu \mathrm{L} \mathrm{SYBR}^{\circledR}$ Primer Ex Taq ${ }^{\mathrm{TM}}$ II (TaKaRa). Thermal cycling parameters were as follows: 1 cycle at $95^{\circ} \mathrm{C}$ for $3 \mathrm{~min}$, followed by 40 cycles of denaturation at $95^{\circ} \mathrm{C}$ for $5 \mathrm{~s}$ and annealing at the appropriate temperature (Table 1) for $30 \mathrm{~s}$. The specificity of the PCR products was further confirmed by a melting curve analysis. All PCR amplifications were performed in triplicate for each sample, and gene expression levels were quantified for $\beta$-actin to obtain relative levels by using the $2^{-\Delta \Delta \mathrm{Ct}}$ method (Livak and Schmittgen, 2001).

\section{Statistical analysis}

Gene expression data were subjected to analysis of variance (ANOVA) by using the procedures of SAS (The SAS V8.0; SAS Institute, Cary, NC, USA). Significant differences between treatments were tested using the Duncan new multiple test (The SAS V8.0). Data are reported as means \pm standard error, and significance level was $\mathrm{P}<0.05$. Relationships between traits were assessed using Pearson's coefficient correlation analyses.

\section{RESULTS}

\section{Fat-related traits in different rearing systems}

In the different rearing systems, traits BW, SFT, AFW, and IMF of free-range chickens were significantly lower than those of the caged chickens $(\mathrm{P}<0.05)$. All traits were the greatest in the caged chickens and lowest in the free-range birds, except for IMF. The indoor-floor raised group had lower IMF content than that of the free-ranged group, although differences were not significant (Table 2).

Table 2. Effects of different housing systems on fat-related traits.

\begin{tabular}{lccccc}
\hline & \multicolumn{5}{c}{ Related traits } \\
\cline { 2 - 6 } Housing system & BW $(\mathrm{kg})$ & SFT $(\mathrm{mm})$ & AFW $(\mathrm{g})$ & AFP $(\%)$ & IMF $(\%)$ \\
\hline Caged & $2984.7 \pm 97.9^{\mathrm{a}}$ & $9.80 \pm 0.34^{\mathrm{a}}$ & $113.48 \pm 7.17^{\mathrm{a}}$ & $3.91 \pm 0.30$ & $3.01 \pm 0.19^{\mathrm{a}}$ \\
Indoor floor & $2853.2 \pm 97.9^{\mathrm{a}}$ & $8.58 \pm 0.35^{\mathrm{b}}$ & $99.71 \pm 7.37^{\mathrm{ab}}$ & $3.71 \pm 0.31$ & $2.41 \pm 0.20^{\mathrm{b}}$ \\
Free-range & $2460.4 \pm 100.5^{\mathrm{b}}$ & $8.53 \pm 0.34^{\mathrm{b}}$ & $84.64 \pm 7.17^{\mathrm{b}}$ & $3.35 \pm 0.31$ & $2.87 \pm 0.21^{\text {ab }}$ \\
\hline
\end{tabular}

$\mathrm{BW}=$ body weight; SFT = subcutaneous fat thickness; AFW = abdominal fat weight; AFP = abdominal fat percentage; IMF = intramuscular fat content. Means without the same superscript letter in a columm indicate that the difference between groups was significant. 


\section{Effects of different rearing systems on the expression abundance of lipogenic genes}

Under different rearing systems, the mRNA abundance of $L X R \alpha$ was not altered, while the mRNA abundance of ChREBP, SREBP1, and FAS showed significant differences $(\mathrm{P}<0.05)$ between the caged and free-range groups. However, almost all the genes showed a similar expression pattern, where abundance was the greatest in the caged group and lowest in the free-range group (Table 3).

Table 3. Effects of different rearing systems on the expression abundance of lipogenic genes.

\begin{tabular}{lcccc}
\hline Housing system & \multicolumn{4}{c}{ Expression abundance } \\
\cline { 2 - 5 } & LXR & ChREBP & SREBPI & FAS \\
\hline Caged & $0.042 \pm 0.0052$ & $0.089 \pm 0.0071^{\mathrm{a}}$ & $0.0087 \pm 0.0010^{\mathrm{a}}$ & $0.45 \pm 0.042^{\mathrm{a}}$ \\
Indoor floor & $0.041 \pm 0.0052$ & $0.057 \pm 0.0075^{\mathrm{b}}$ & $0.0027 \pm 0.0010^{\mathrm{b}}$ & $0.32 \pm 0.043^{\mathrm{b}}$ \\
Free-range & $0.037 \pm 0.0049$ & $0.037 \pm 0.0071^{\mathrm{b}}$ & $0.0033 \pm 0.0011^{\mathrm{b}}$ & $0.12 \pm 0.043^{\mathrm{c}}$ \\
\hline
\end{tabular}

$L X R \alpha=$ liver $\mathrm{X}$ receptor $\alpha ; C h R E B P=$ carbohydrate response element-binding protein; $S R E B P 1=$ sterol regulatory element-binding protein-1; $F A S=$ fatty acid synthase.

\section{Association between gene expression abundance and fat traits}

The results showed that mRNA expression levels of the 4 lipogenic genes were positively correlated with each other. Any 2 genes showed significant $(\mathrm{P}<0.05)$ or highly significant $(\mathrm{P}<0.01)$ positive correlations, except for $L X R \alpha$ and SREBP1.

The association analysis between gene expression and fat traits showed that there was a significant $(\mathrm{P}<0.05)$ or highly significant $(\mathrm{P}<0.01)$ positive correlation between the expression of ChREBP and SFT, AFW, and AFP. A similar positive correlation was found between SREBP1 and SFT and AFW (Table 4).

\begin{tabular}{|c|c|c|c|c|c|c|c|c|}
\hline \multirow[t]{3}{*}{ Genes } & \multicolumn{8}{|c|}{ Correlation coefficient $\mathrm{R}$} \\
\hline & \multicolumn{4}{|c|}{ Gene } & \multicolumn{4}{|c|}{ Fat traits } \\
\hline & $L X R \alpha$ & ChREBP & SREBPI & $F A S$ & SFT & AFW & AFP & IMF \\
\hline$L X R \alpha$ & & $0.47 * *$ & 0.11 & $0.27 *$ & 0.20 & 0.15 & 0.25 & 0.0086 \\
\hline ChREBP & $0.47 * *$ & & $0.70^{* *}$ & $0.84 * *$ & $0.26^{*}$ & $0.34 *$ & $0.38 *$ & 0.074 \\
\hline SREBPI & 0.11 & $0.70^{* *}$ & & $0.77^{* *}$ & $0.32 *$ & $0.33^{*}$ & 0.24 & 0.070 \\
\hline FAS & $0.27 *$ & $0.84^{* *}$ & $0.77 * *$ & & 0.21 & 0.14 & 0.14 & -0.030 \\
\hline
\end{tabular}

$L X R \alpha=$ liver $\mathrm{X}$ receptor $\alpha$; ChREBP = carbohydrate response element-binding protein; $S R E B P 1=$ sterol regulatory element-binding protein-1; $F A S=$ fatty synthase. SFT = subcutaneous fat thickness; $A F W=$ abdominal fat weight; $\mathrm{AFP}=$ abdominal fat percentage; $\mathrm{IMF}=$ intramuscular fat content. ${ }^{*}, * *$ Significant correlation between parameters at the levels of $\mathrm{P}<0.05$ and 0.01 , respectively.

\section{DISCUSSION}

In the present study, we found that traits BW, SFT, AFW, AFP, and IMF of the freerange group were remarkably lower than those of caged chickens. This is consistent with the findings of other studies that reported how free-range system reduced growth performances 
and fat deposition in broilers. Similar results were obtained in introduced broilers and native breeds in China most likely due to the fluctuating temperatures and increased exercise in the free-range system, which increases the energy requirement and expenditure of chickens (Wang et al., 2009a), where myogenesis is favored instead of lipogenesis (Lei and Van Beek, 1997; Castellini et al., 2002; Fanatico et al., 2007). Meanwhile, although the same complete diet was provided to all birds in the current study, the free-range group consumed pasture during the day time, with only supplementary feeding of the complete diet in the morning and night, which could lead to unbalanced dietary energy intake in these birds. Previous study found that the abdominal fat increased when the dietary energy and protein levels increased (Wang et al., 2012).

Meanwhile, we found that the free-range birds had significantly higher IMF than those of the indoor-floor housed group. This is because low dietary nutrient density might lead to insufficient energy and protein intake, which might further cause a wide range of muscle imbalance in energy metabolism, thus contributing to the increase in IMF content (Gondret and Lebret, 2002). A higher IMF content improves the tenderness and flavor of meat (Wang et al., 2013). However, increased abdominal fat wastes feed resources and is not desirable. In the current study, we found that birds from the free-range rearing system had lower SFT and AF and higher IMF, which adequately satisfies the meat quality demands of customers in China and lower energy cost requirement of farmers. It is an ideal housing system for producing high quality chicken in a niche market.

On the basis of the phenotypic differences among the 3 housing systems in fat-related traits, we further investigated the expression of genes involved in lipogenesis from these systems. $L X R \alpha$ together with ChREBP and SREBPI can regulate de novo lipogenesis directly or indirectly through the final central enzyme FAS (Tabor et al., 1999; Joseph et al., 2002; Uyeda and Repa, 2006). In the present study, we found that the rearing system had a significant effect on the mRNA abundance of ChREBP, SREBP1, and FAS. All genes showed a similar expression pattern in chickens from different housing systems, while abundance was the greatest in the liver of caged chickens and lowest in the liver of the free-range birds. This is probably because free-range birds consumed less daily total energy while expending proportionally more energy on physical activity. Similar results were observed, in which nutrient restriction was found to block the expression of lipogenic transcription factor SREBPl and its target genes (Wang et al., 2009a), and aerobic exercise was found to inhibit mRNA expression of liver ChREBP in rats fed high-sugar and high-fat diets. The mRNA abundance of $L X R \alpha$ showed no difference among housing systems, which is consistent with the reports that $L X R \alpha$ gene is constitutively expressed in all chicken tissues, while it is exclusively expressed in the liver and adipose tissues of mammals (Archer et al., 2013).

The correlation analysis among gene expressions showed that mRNA expressions of $L X R \alpha, C h R E B P$, and SREBP1 were positively correlated with those of FAS. This finding is consistent with those of other studies where the expression of $F A S$ was found to be regulated by $L X R \alpha, C h R E B P$, and SREBP1, as well as by their interactions (Tabor et al., 1999; Joseph et al., 2002; Uyeda and Repa, 2006; Denechaud et al., 2008). The expression of $L X R \alpha$ was positively correlated with that of $C h R E B P$, while there was no significant correlation between the expression abundance of $L X R \alpha$ and SREBP1. This is because the expression of ChREBP and $S R E B P 1$ is determined by some transcription factors, which include $L X R \alpha$ and some posttranslational regulators (Proszkowiec-Weglarz et al., 2008). 
Housing system is a key environment factor affecting the expression of lipogenetic genes, the expressions of which are affected by factors, including light, temperature, density, startle (Hester et al., 2005), diet intake (Ponte et al., 2008), and exercise amount (Wang et al., $2009 \mathrm{~b}$ ). The results of the present study indicated that chicken from the caged group had higher SFT, AFW, AFP, and IMF as well as higher mRNA levels of $L X R \alpha, C h R E B P, S R E B P 1$, and $F A S$ in the liver than those of the free-range group, which implied that the above-mentioned complex factors in a confined system probably lead to obese chickens by affecting the lipogenetic genes. There were positive correlations between the mRNA abundance of SREBPI and traits SFT and AFW. Some studies have shown that these 2 genes play an important role in lipogenesis (Ferre and Foufelle, 2007, 2010; Poupeau and Postic, 2011).

In summary, our study indicated that birds from a caged system have heavier abdominal and subcutaneous fat and higher IMF. Genes ChREBP and SREBP1 are expressed in higher levels in the liver of caged birds than in those of free-ranged birds. Positive correlations were found between fat traits and gene expression of ChREBP and SREBP1. These results indicated that increased fat deposition in chicken was probably a result of increased gene expression of ChREBP and SREBP1 in the liver.

\section{ACKNOWLEDGMENTS}

We thank Xiu-Li Mei, Li Xie, Qin Yang, and Mo-Han Qiu for sample collection and technical support. Research supported by the National Agriculture Research System (project \#CARS-41) and the National Natural Science Foundation of China (\#31402070).

\section{REFERENCES}

Archer A, Stolarczyk E, Doria ML, Helguero L, et al. (2013). LXR activation by GW3965 alters fat tissue distribution and adipose tissue inflammation in ob/ob female mice. J. Lipid Res. 54: 1300-1311.

Castellini C, Mugnai C and Dal Bosco A (2002). Effect of organic production system on broiler carcass and meat quality. Meat Sci. 60: 219-225.

Cha JY and Repa JJ (2007). The liver X receptor (LXR) and hepatic lipogenesis. The carbohydrate-response elementbinding protein is a target gene of LXR. J. Biol. Chem. 282: 743-751.

Chu K, Miyazaki M, Man WC and Ntambi JM (2006). Stearoyl-coenzyme A desaturase 1 deficiency protects against hypertriglyceridemia and increases plasma high-density lipoprotein cholesterol induced by liver X receptor activation. Mol. Cell Biol. 26: 6786-6798.

Clarke SD (1993). Regulation of fatty acid synthase gene expression: an approach for reducing fat accumulation. J. Anim. Sci. 71: 1957-1965.

Demeure O, Duby C, Desert C, Assaf S, et al. (2009). Liver X receptor alpha regulates fatty acid synthase expression in chicken. Poult. Sci. 88: 2628-2635.

Denechaud PD, Bossard P, Lobaccaro JM, Millatt L, et al. (2008). ChREBP, but not LXRs, is required for the induction of glucose-regulated genes in mouse liver. J. Clin. Invest. 118: 956-964.

Dentin R, Girard J and Postic C (2005). Carbohydrate responsive element binding protein (ChREBP) and sterol regulatory element binding protein-1c (SREBP-1c): two key regulators of glucose metabolism and lipid synthesis in liver. Biochimie 87: 81-86.

Ducheix S, Lobaccaro JM, Martin PG and Guillou H (2011). Liver X Receptor: an oxysterol sensor and a major player in the control of lipogenesis. Chem. Phys. Lipids 164: 500-514.

Fanatico AC, Pillai PB, Cavitt LC, Emmert JL, et al. (2006). Evaluation of slower-growing broiler genotypes grown with and without outdoor access: sensory attributes. Poult. Sci. 85: 337-343.

Fanatico AC, Pillai PB, Emmert JL and Owens CM (2007). Meat quality of slow- and fast-growing chicken genotypes fed low-nutrient or standard diets and raised indoors or with outdoor access. Poult. Sci. 86: 2245-2255.

Ferre P and Foufelle F (2007). SREBP-1c transcription factor and lipid homeostasis: clinical perspective. Horm. Res. 68: 
$72-82$.

Ferre P and Foufelle F (2010). Hepatic steatosis: a role for de novo lipogenesis and the transcription factor SREBP-1c. Diabetes Obes. Metab. (Suppl 2): 83-92.

Gondret F and Lebret B (2002). Feeding intensity and dietary protein level affect adipocyte cellularity and lipogenic capacity of muscle homogenates in growing pigs, without modification of the expression of sterol regulatory element binding protein. J. Anim. Sci. 80: 3184-3193.

Griffin H and Hermier D (1988). Plasma Lipoprotein Metabolism and Fattening in Poultry. Leanness in Domestic Birds. INRA-Butterworths and Co, London, 175-202.

Hester PY, Alvarado CZ, Bilgili SF, Denton JH, et al. (2005). Planning our future: the Poultry Science Association strategic plan. Poult. Sci. 84: 1814-1815.

Jones RB and Mills AD (1999). Divergent selection for social reinstatement behaviour in Japanese quail: effects on sociality and social discrimination. Poult. Avian Biol. Rev. 10: 213-223.

Joseph SB, Laffitte BA, Patel PH, Watson MA, et al. (2002). Direct and indirect mechanisms for regulation of fatty acid synthase gene expression by liver X receptors. J. Biol. Chem. 277: 11019-11025.

Lei $S$ and van Beek G (1997). Influence of activity and dietary energy on broiler performance, carcase yield and sensory quality. Br. Poult. Sci. 38: 183-189.

Livak KJ and Schmittgen TD (2001). Analysis of relative gene expression data using real-time quantitative PCR and the 2(-Delta Delta C(T)) method. Methods 25: 402-408.

Magana MM, Lin SS, Dooley KA and Osborne TF (1997). Sterol regulation of acetyl coenzyme A carboxylase promoter requires two interdependent binding sites for sterol regulatory element binding proteins. J. Lipid Res. 38: 1630-1638.

Marin RH, Freytes P, Guzman D and Bryan JR (2001). Effects of an acute stressor on fear and on the social reinstatement responses of domestic chicks to cagemates and strangers. Appl. Anim. Behav. Sci. 71: 57-66.

Mendl M (1999). Performing under pressure: stress and cognitive function. Appl. Anim. Behav. Sci. 65: 221-244.

Ponte PI, Alves SP, Bessa RJ, Ferreira LM, et al. (2008). Influence of pasture intake on the fatty acid composition, and cholesterol, tocopherols, and tocotrienols content in meat from free-range broilers. Poult. Sci. 87: 80-88.

Poupeau A and Postic C (2011). Cross-regulation of hepatic glucose metabolism via ChREBP and nuclear receptors. Biochim. Biophys. Acta 1812: 995-1006.

Proszkowiec-Weglarz M, Humphrey BD and Richards MP (2008). Molecular cloning and expression of chicken carbohydrate response element binding protein and Max-like protein X gene homologues. Mol. Cell Biochem. 312: 167-184.

Repa JJ, Liang G, Ou J, Bashmakov Y, et al. (2000). Regulation of mouse sterol regulatory element-binding protein-1c gene (SREBP-1c) by oxysterol receptors, LXRalpha and LXRbeta. Genes Dev. 14: 2819-2830.

Tabor DE, Kim JB, Spiegelman BM and Edwards PA (1999). Identification of conserved cis-elements and transcription factors required for sterol-regulated transcription of stearoyl-CoA desaturase 1 and 2. J. Biol. Chem. 274: 20603-20610.

Talukdar S and Hillgartner FB (2006). The mechanism mediating the activation of acetyl-coenzyme A carboxylase-alpha gene transcription by the liver X receptor agonist T0-901317. J. Lipid Res. 47: 2451-2461.

Uyeda K and Repa JJ (2006). Carbohydrate response element binding protein, ChREBP, a transcription factor coupling hepatic glucose utilization and lipid synthesis. Cell Metab. 4: 107-110.

Wang PH, Ko YH, Chin HJ, Hsu C, et al. (2009a). The effect of feed restriction on expression of hepatic lipogenic genes in broiler chickens and the function of SREBP1. Comp. Biochem. Physiol. B Biochem. Mol. Biol. 153: 327-331.

Wang KH, Shi SR, Dou TC and Sun HJ (2009b). Effect of a free-range raising system on growth performance, carcass yield, and meat quality of slow-growing chicken. Poult. Sci. 88: 2219-2223.

Wang W, Xue W, Jin B, Zhang X, et al. (2013). Candidate gene expression affects intramuscular fat content and fatty acid composition in pigs. J. Appl. Genet. 54: 113-118.

Wang XX, Wang ZY, Yang HM and Cao YJ (2012). Effects of dietary energy and protein level and lysine level on body weight and slaughter performance of Yangzhou Geese at the age of 5 to 10 weeks. Chin. J. Anim. Nutr. 24: 10441051.

Wood JD, Enser M, Fisher AV, Nute GR, et al. (2008). Fat deposition, fatty acid composition and meat quality: A review. Meat Sci. 78: 343-358.

Zerehdaran S, Vereijken AL, van Arendonk JA and van der Waaijt EH (2004). Estimation of genetic parameters for fat deposition and carcass traits in broilers. Poult. Sci. 83: 521-525.

Zhao XL, Siegel PB, Liu YP, Wang Y, et al. (2012). Housing system affects broiler characteristics of local Chinese breed reciprocal crosses. Poult. Sci. 91: 2405-2410. 